\title{
Evaluating Effectiveness with Regard to the Implementation of the SMED Method for A Flexographic Machine
}

\author{
- A case study
}

\author{
Krzysztof Ejsmont \\ Faculty of Production Engineering \\ Warsaw University of Technology \\ Warsaw, Poland \\ e-mail: krzysztof.ejsmont@wp.pl
}

\author{
Jan Lipiak \\ Faculty of Production Engineering \\ Warsaw University of Technology \\ Warsaw, Poland \\ e-mail: janlipiak@etigraf.pl
}

\begin{abstract}
This paper aims to present a process of implementing a Single-Minute Exchange of Die (SMED) method and a manner of evaluating the effectiveness of such an undertaking. The subject of the study is a printing enterprise that conducts its business activity in Poland and the chosen research area is a flexographic machine Gidue Master Combat 430. The article presents specific stages of implementing the SMED method, describes activities aimed at determining the causes of the resulting waste and proposes ways of improving the changeover process. It should be emphasised that the article presents the effectiveness of implementing the SMED method in a measurable and quantitative manner.
\end{abstract}

Keywords-lean manufacturing; flexographic machine changeover; elimination of waste; SMED method

\section{INTRODUCTION}

In the era of globalisation, striving for perfection in manufacturing is crucial to survive on the market and develop the enterprise [1, 2, 3]. Each company chooses its own path to excellence by implementing different concepts and methods such as: Lean Manufacturing, Agile Manufacturing, Sustainable Manufacturing and building their own models of excellence [4, 5, 6, 7]. The purpose of these activities is to search for various types of losses, to introduce actions that eliminate their occurrence and to identify opportunities for increasing the effectiveness.

The philosophy of Lean and its practices have emerged as one of the most successful and widely used systems in today's world. Many researchers have recommended Lean as a very effective system for making an organization better and more capable [8, 9]. The focus of Lean is about waste elimination. Waste in Lean, is defined as anything that does not add value to the product or service from a customer's perspective [10].Since waste elimination is one of the Lean objectives, it is crucial for companies to identify wastes relevant to: defects, waiting time, overproduction, transportation, inventory, unused creativity and over processing. To identify the waste and take actions striving for eliminating or limiting them, operational perspective needs to be applied. Lean from an operational perspective involves implementing a set of shop floor tools and techniques aimed at reducing waste within the plant. Such tools and techniques include, for example, setup time reduction
(SMED), work standardization, kaizen, visual displays (e.g. 5S), Kanban and preventative maintenance.

Resetting machines and production devices in order to prepare them for manufacturing a new product requires time. Finding resources for its reduction is the objective of the managers that are in charge of production processes. The subject of changeovers appears particularly crucial in the printing sector. It is quite common that changeover time for multicolour printing exceeds an hour, whereas the process of printing takes no longer than several minutes. The reason for this state of affairs is the fact that flexographic machines can print at the speed of 3,000 m per $1 \mathrm{~h}$, and approximately $20-25 \%$ of all orders in printing companies do not exceed 200 linear metres. Therefore, it is justified to analyse the process of changeover and to identify opportunities of improvement. To achieve this goal one of Lean tools was used - SMED method.

\section{Characteristics OF THE SMED MethoD}

One of the factors influencing the availability of production equipment and thus the effectiveness of its use is the changeover of machines or whole production lines. Changeover time is the time elapsing between the execution of the last part of the current batch and the start of the production of the first compatible part from the new batch. This time can also be defined from the perspective of "loss", then it is the sum of lost production during the time span between the last good part produced at the previous set-up and the first good part produced at the new set-up. Shiego Shingo's SMED (Single Minute Exchange of Die) method is the answer to finding ways to shorten the time of changeovers. The idea of the method is based on eliminating the causes of machine downtime during changeover process. It has identified four stages in the organization of the process of changeover: (0) preparatory activities, (1) analysis of the recorded changeover process, (2) transformation of internal activities into external, (3) rationalization of all aspects of changeovers.

If the SMED method is performed correctly, there is a radical reduction in the changeover time of the machine, which in turn contributes to $[12,13]$ :

- higher efficiency of equipment and better use of them, 
- unlock the stock buffers,

- eliminating waste and non-value added activities,

- increase the flexibility of production.

In the context of the entire enterprise, shortening of the changeover time allows $[14,15,16]$ :

- increased flexibility - easier and faster adaptation to market changes and customer requirements,

- shortening lead time - ordered products are delivered to the customer in shorter time,

- improvement of product quality - rational organization of the changeover process limits the size of the trial series; the number of deficiencies resulting from machine calibration errors is reduced,

- increased productivity - shorter preparation times reduce machine downtime.

\section{IDENTIFYING LOSS IN THE PRINTING COMPANY}

To determine the cost of lost production for the changeovers, the data from the whole year 2016 was gathered with regard to various types of waste that occurred in the organisation and Pareto-Lorentz analysis was prepared (Fig. 1).

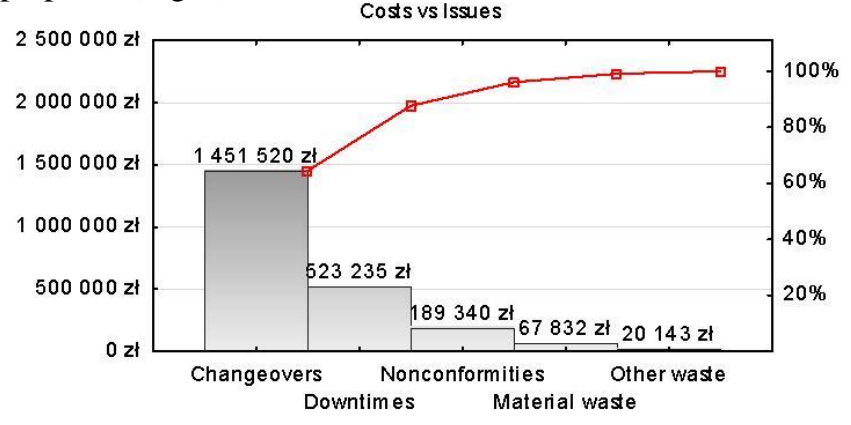

Figure 1. Waste analysis in the printing company in 2016

The analysis indicated that changeover-related waste was the most severe factor and comprised approx. $60 \%$ of all waste (in 2016 the average daily number of changeovers was 8 and an average time was 1.2 hour (Table 1)).

TABLE I. FleXogaphic Machine Downtime (Average Values IN 2016)

\begin{tabular}{|l|c|c|c|}
\hline \multirow{2}{*}{ No. } & \multicolumn{3}{|c|}{ Characteristics of data per one working day } \\
\cline { 2 - 4 } & Name & Unit & Value \\
\hline 1 & $\begin{array}{c}\text { Cost of one man-hour work of the } \\
\text { printing machine }\end{array}$ & {$[\mathrm{PLN} / \mathrm{h}]$} & 600 \\
\hline 2 & $\begin{array}{c}\text { Number of performed orders } \\
{[\mathrm{pcs}]}\end{array}$ & 8 \\
\hline 3 & Number of machine changeovers & {$[\mathrm{pcs}]$} & 8 \\
\hline 4 & Average time of one changeover & {$[\mathrm{h}]$} & 1.2 \\
\hline 5 & Working time of the machine & {$[\mathrm{h}]$} & 20 \\
\hline 6 & Changeover-related downtime time & {$[\mathrm{h}]$} & 9.6 \\
\hline 7 & Effective working time & {$[\mathrm{h}]$} & 10.4 \\
\hline
\end{tabular}

TABLE II. IMPLEMENTATION SCHEME FOR THE SMED METHOD

\begin{tabular}{|c|c|c|}
\hline \multirow[b]{2}{*}{ Stage } & \multicolumn{2}{|r|}{ Description of activities } \\
\hline & $\begin{array}{c}\text { Name of the } \\
\text { activity }\end{array}$ & Characteristics \\
\hline \multirow{3}{*}{0} & $\begin{array}{l}\text { choosing the } \\
\text { area for SMED } \\
\text { implementation }\end{array}$ & $\begin{array}{l}\text { Flexographic printing machine Gidue } \\
\text { Master Combat } 430\end{array}$ \\
\hline & $\begin{array}{l}\text { appointing an } \\
\text { implementation } \\
\text { team }\end{array}$ & $\begin{array}{l}\text { The team was composed of the printer and } \\
\text { two assistants who perform daily } \\
\text { operations at the machine, as well as the } \\
\text { production manager and the plant's } \\
\text { director - it was crucial to engage the top } \\
\text { management into the entire process }\end{array}$ \\
\hline & $\begin{array}{l}\text { training the } \\
\text { team within the } \\
\text { SMED } \\
\text { methodology }\end{array}$ & $\begin{array}{l}\text { Providing the necessary knowledge on } \\
\text { major assumptions and goals of the } \\
\text { implemented method as well as } \\
\text { information that can foster its proper } \\
\text { implementation }\end{array}$ \\
\hline \multirow[b]{2}{*}{1} & $\begin{array}{l}\text { filming the } \\
\text { changeover } \\
\text { process, }\end{array}$ & $\begin{array}{l}\text { Arranging the date and informing the team } \\
\text { on the filming objectives - it is crucial that } \\
\text { employees behave naturally and perform } \\
\text { their work in a standard manner }\end{array}$ \\
\hline & $\begin{array}{l}\text { reviewing and } \\
\text { analysing the } \\
\text { video tape }\end{array}$ & $\begin{array}{l}\text { At this immensely crucial stage the } \\
\text { principal task is to describe specific } \\
\text { activities during a changeover, their } \\
\text { categorisation into internal and external } \\
\text { activities and the designation of operation } \\
\text { timings }\end{array}$ \\
\hline \multirow[b]{2}{*}{2} & brainstorming & $\begin{array}{c}\text { Ideas for improving changeovers, replacing } \\
\text { internal activities with external ones, } \\
\text { shortening internal activities, etc. }\end{array}$ \\
\hline & execution plan & $\begin{array}{l}\text { Determining and selecting activities that } \\
\text { facilitate the implementation and shorten } \\
\text { the changeover time as well as eliminate or } \\
\text { minimise related problems }\end{array}$ \\
\hline \multirow{3}{*}{3} & $\begin{array}{c}\text { new changeover } \\
\text { trial }\end{array}$ & $\begin{array}{l}\text { Testing changeover operations upon the } \\
\text { implementation of previously planned } \\
\text { improvement activities }\end{array}$ \\
\hline & $\begin{array}{c}\text { process } \\
\text { standardisation }\end{array}$ & $\begin{array}{l}\text { Standardising the changeover process after } \\
\text { the implementation of changes }\end{array}$ \\
\hline & $\begin{array}{l}\text { continuous } \\
\text { improvement }\end{array}$ & $\begin{array}{l}\text { A test after one month from the } \\
\text { implementation of the changeover process }\end{array}$ \\
\hline
\end{tabular}

It can also be observed (Table 1) that the indicator for effective working time of the machine with regard to changeover-related downtimes is low $(9.6 \mathrm{~h}$ of downtime per $20 \mathrm{~h}$ of the machine's work, which makes the indicator for effective working time of the machine equal 52\%). 
Although a high value of time related with machines' downtime in the flexographic sector due changeovers is specific for the printing sector nonetheless, such a high indicator for machine changeover is unacceptable by the board of company - even in the light of the specifics of flexography.

The company's management decided that an analysis should be made of the losses occurring during the changeovers of the machines. To achieve this goal, a SMED method has been chosen in accordance with the principles defined in $[11,17]$. The implementation of the method takes place in 4 stages (Table 2) and requires the involvement of management [18].

\section{IMPLEMENTATION OF THE SMED METHOD}

In order to analysis of the changeover process, the machine Gidue Master Combat 430 (Fig. 2) was selected. This is a critical machine for the enterprise. This machine is used for producing shrink sleeves that are the company's key product in the company's offer.

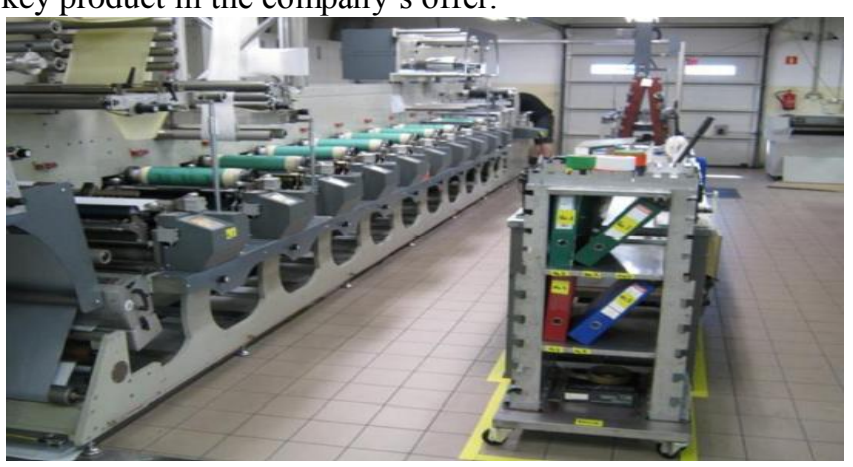

Figure 2. Printing machine Gidue Master Combat 430

After receiving a list of production orders, the machine operator independently (mostly relying on his experience and knowledge) arranges the schedule of orders based on their execution dates, colour scheme, type and width of the raw material etc. The organisation of orders is primarily determined by changeover time that is usually a few times longer than the time that is devoted to the printing process itself. It also happens (especially in low-stock orders) that the machine's changeover time exceeds an hour and the printing process itself takes merely a few minutes. In such cases shortening the changeover time is a critical point.

The analysis was initiated by observing the entire machine changeover process in the course of the execution of one production order. The order in question was the socalled secondary imposition, i.e. an order executed again with the use of already existing printing plates - namely polymers from previous orders. It is of note that in this case the shortening involved activities connected with preparing appropriate plates.

All activities that were performed by the machine's operator have been recorded during the changeover with their duration times (Table 3). This also led to the distinction of internal and external activities and their categorisation into groups.

- VA - value added activities,
- VA/NVA - intermediary activities,

- NVA - non-value added activities.

TABLE III. FLEXOGRAPGING MACHINE CHANGEOVER

\begin{tabular}{|c|c|c|c|c|}
\hline \multirow[b]{2}{*}{ No. } & \multicolumn{4}{|c|}{ Description of the activity } \\
\hline & Name & Value & Time [s] & $\begin{array}{l}\text { Internal/ } \\
\text { External }\end{array}$ \\
\hline 1 & $\begin{array}{l}\text { Machine's stopover, } \\
\text { issuing a sheet }\end{array}$ & VA/NVA & 20 & $\mathrm{E}$ \\
\hline 2 & $\begin{array}{l}\text { Removing the roll with the } \\
\text { finished product }\end{array}$ & VA & 15 & I \\
\hline 3 & $\begin{array}{l}\text { Sample archiving, further } \\
\text { issuing of documents }\end{array}$ & VA/NVA & 53 & $\mathrm{E}$ \\
\hline 4 & $\begin{array}{l}\text { Receiving and assembling } \\
\text { rubber gloves }\end{array}$ & NVA & 37 & $\mathrm{E}$ \\
\hline 5 & Removing the roll from $\mathrm{Z3}$ & VA & 15 & I \\
\hline 6 & Washing Z3 & VA/NVA & 33 & I \\
\hline 7 & Polymer archiving & VA/NVA & 22 & $\mathrm{E}$ \\
\hline 8 & $\begin{array}{l}\text { Fetching the abrasive, } \\
\text { walking - bin }\end{array}$ & NVA & 10 & $\mathrm{E}$ \\
\hline 9 & $\begin{array}{l}\text { Washing the roll at the } \\
\text { washer }\end{array}$ & VA/NVA & 50 & $\mathrm{E}$ \\
\hline 10 & Walking - bin & NVA & 10 & E \\
\hline 11 & $\begin{array}{l}\text { Taking away the roll - } \\
\text { trolley }\end{array}$ & NVA & 20 & $\mathrm{E}$ \\
\hline 12 & $\begin{array}{c}\text { Fetching the roll from Z3 - } \\
\text { path to the washer }\end{array}$ & VA & 5 & I \\
\hline 13 & $\begin{array}{l}\text { Washing the roll at the } \\
\text { washer }\end{array}$ & VA/NVA & 50 & $\mathrm{E}$ \\
\hline 14 & $\begin{array}{l}\text { Taking away the roll - } \\
\text { trolley }\end{array}$ & NVA & 12 & $\mathrm{E}$ \\
\hline 15 & $\begin{array}{l}\text { Fetching and washing the } \\
\text { ink tray }\end{array}$ & VA & 223 & $\mathrm{E}$ \\
\hline 16 & $\begin{array}{l}\text { Walking to fetch the } \\
\text { pantone }\end{array}$ & NVA & 220 & $\mathrm{E}$ \\
\hline 17 & $\begin{array}{l}\text { Filling the ink tray with } \\
\text { the pantone }\end{array}$ & VA/NVA & 65 & $\mathrm{E}$ \\
\hline 18 & $\begin{array}{l}\text { Bringing back the roll with } \\
\text { the finished product }\end{array}$ & VA/NVA & 35 & $\mathrm{E}$ \\
\hline 19 & $\begin{array}{l}\text { Removing the roll with } \\
\text { waste }\end{array}$ & VA/NVA & 15 & I \\
\hline 20 & $\begin{array}{l}\text { Mounting a new roll with } \\
\text { waste }\end{array}$ & VA/NVA & 40 & I \\
\hline 21 & Reading the sheet & NVA & 20 & $\mathrm{E}$ \\
\hline 22 & $\begin{array}{l}\text { Dismounting and archiving } \\
\text { the die }\end{array}$ & VA & 115 & $\mathrm{E}$ \\
\hline
\end{tabular}




\begin{tabular}{|c|c|c|c|c|}
\hline \multirow[b]{2}{*}{ No. } & \multicolumn{4}{|c|}{ Description of the activity } \\
\hline & Name & Value & Time $[s]$ & $\begin{array}{l}\text { Internal/ } \\
\text { External }\end{array}$ \\
\hline 23 & Walking to fetch the die & NVA & 170 & $\mathrm{E}$ \\
\hline 24 & Mounting the die & VA & 130 & I \\
\hline 25 & $\begin{array}{l}\text { Dismounting the roll with } \\
\text { the paper }\end{array}$ & VA & 80 & I \\
\hline 26 & Walking to fetch 4 rolls & NVA & 100 & $\mathrm{E}$ \\
\hline 27 & Searching for polymers & VA/NVA & 80 & $\mathrm{E}$ \\
\hline 28 & $\begin{array}{l}\text { Walking - explaining the } \\
\text { process sheet }\end{array}$ & NVA & 90 & $\mathrm{E}$ \\
\hline 29 & $\begin{array}{l}\text { Labelling and mounting } 4 \\
\text { rolls }\end{array}$ & VA/NVA & 365 & I \\
\hline 30 & Walking to fetch the paper & NVA & 190 & $\mathrm{E}$ \\
\hline 31 & Mounting a roll of paper & $\overline{\mathrm{VA}}$ & 65 & I \\
\hline 32 & $\begin{array}{l}\text { Regulating the printing } \\
\text { imposition }\end{array}$ & VA & 785 & I \\
\hline 33 & Controlling the first trial & VA & 65 & I \\
\hline 34 & $\begin{array}{l}\text { Replacing the ink roll with } \\
\text { Z4 }\end{array}$ & VA & 45 & I \\
\hline 35 & $\begin{array}{l}\text { Walking to fetch the } \\
\text { receiver tube }\end{array}$ & NVA & 85 & $\mathrm{E}$ \\
\hline 36 & $\begin{array}{c}\text { Another printing } \\
\text { imposition }\end{array}$ & VA & 160 & I \\
\hline
\end{tabular}

In order to analyse activities performed in the course of changeover, the authors decided to use a Gantt chart (Fig. 3). Analysis showed that all activities were performed in series (each activity started after the end of the previous one). The Gantt chart also provided a basis for defining internal and external activities in accordance with the SMED assumptions.

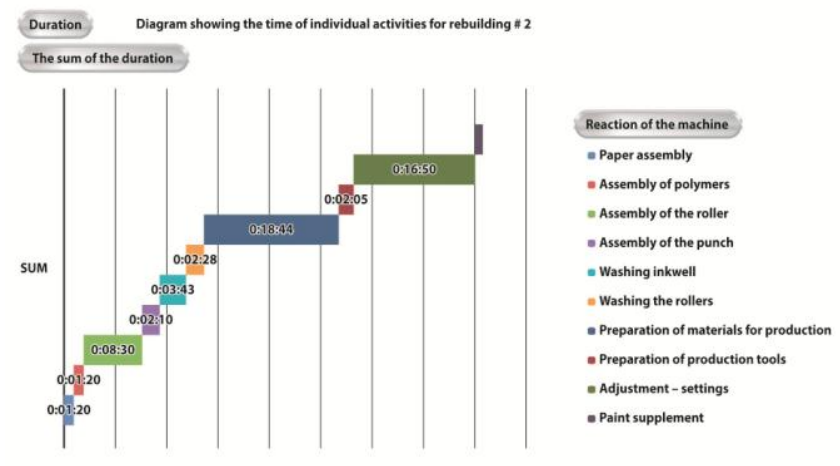

Figure 3. Gantt chart of activities performed during changeover time

In table 3 grey colours signifies internal activities with their total time of 30 minutes and 18 seconds, which constitutes $52 \%$ of all operations. It needs to be highlighted that printing process took merely 160 seconds. With the use of data gathered in table 3 and those presented in the Gantt chart (Fig. 3), it was possible to identify which activities need to be improved or eliminated. The authors also gained the following information:

1) The total time of imposition was 58 minutes and 15 seconds.

2) The compilation of VA, NVA, VA/NVA activities with summarised times:

- VA-0:28:23, i.e. $48.73 \%$,

- VA/NVA - 0:13:48, i.e. $23.69 \%$,

- $\quad$ NVA-0:16:04, i.e. $27.58 \%$.

The authors observed during changeover a considerable percentage of lost time of non-value added activities $27.58 \%$. This constituted $1 / 4$ of the machine's total downtime time connected with changeover.

All motions of the operator at the printing machine were sketched with the use of the co-called spaghetti diagram one of the tools applied in the Lean philosophy (used in the initial phase), which allows for observing all motion paths in the course of executing changeover (Fig. 4). This tool was used for visualising and analysing real employee motions at the work stand and identifying waste during working operations. It is used for shortening time devoted to walking and limiting redundant employee displacement.

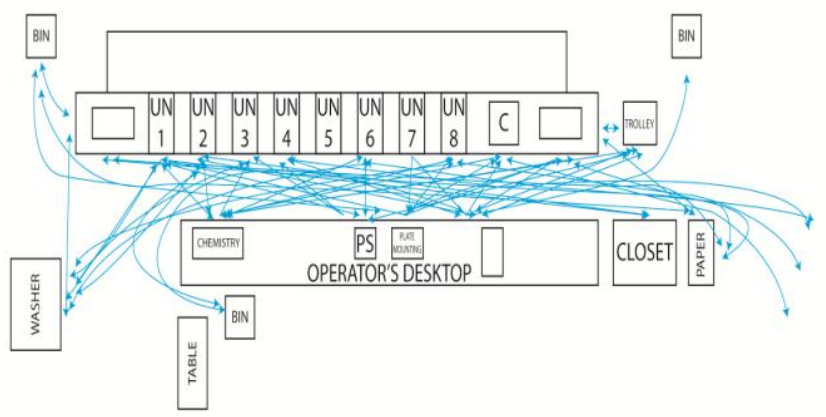

Figure 4. Spaghetti diagram for a work stand with the flexographic machine Gidue Master Combat 430

As figure 4 shows, the path that the printer covered is long and frequently repetitive. It should be emphasised that the diagram disregarded time that the printer devotes to searching for a raw material in the warehouse and bringing it to the machine. Since the printer didn't put back the material after a previously order at the same work shift, these activities weren't necessary. In a converse situation, the changeover time would be longer by several minutes.

\section{Changeover Analysis and Proposals of IMPROVEMENT}

While analysing changeover, it was possible to observe many problems that pointed to wrong work organisation in the printing company. Elements that influenced the lengthening of execution time are:

- excessive number of motions, i.e. a lot of time devoted to searching for components, raw materials, materials needed for executing the order. In the changeover analysis, waste described as "walking" was as long as 13 minutes, 
- long time devoted to preparing and verifying components needed for task execution, such as inks,

- errors in process sheets and the necessity of their explanation caused additional waste of time,

- insufficient number of components, e.g. pantones (mixing inks) needed for order execution,

- mess at work stations, lack of assigned delivery fields and some auxiliary tools (e.g. pallet trucks),

- $\quad$ searching for raw materials for the production and lack of space for storing a finished product.

The problems connected with long downtimes caused by unnecessary printer dislocation in search for fittings and materials led to a decision on reorganising the production hall. The major aim of these activities was to group printing machines in the production centre.

It should be noted that the enterprise has no system for error detection (jidoka) and the printer is obliged to continuously control the correctness and quality of the overprint. In the event of any irregularities, the operator must react immediately, which sometimes may even mean discontinuing the machine's operations. Therefore, the best solution was to employ additional staff for the position of "printer's assistant" (parallel execution of the operations) who will be capable of not only performing external activities independently but also fostering performing internal activities that consume approximately $50 \%$ of changeover time.

According to the assumptions of the second stage of the SMED, it was necessary to lead to a situation in which the time of the machine's shutdown or process changeover is possibly the shortest. For this purpose, internal activities were divided between the machine operator and the assistant. Table 4 presents activities that are performed by two employees in a parallel order.

TABLE IV. DIVISION OF INTERNAL ACTIVITIES

\begin{tabular}{|l|c|c|}
\hline \multirow{2}{*}{ Position } & \multicolumn{2}{|c|}{ Internal activities from table 3 } \\
\cline { 2 - 3 } & Numbers of performed activities & Duration \\
\hline Printer & $24,32,36$ & $\begin{array}{c}17 \text { mins } 55 \\
\text { secs }\end{array}$ \\
\hline $\begin{array}{l}\text { Printer's } \\
\text { assistant }\end{array}$ & $2,5-6,12,19-20,25,29,31,33,34$ & $\begin{array}{c}12 \text { mins } 23 \\
\text { secs }\end{array}$ \\
\hline & Difference & 5 mins 32 secs \\
\hline
\end{tabular}

The operations (Table 4) were divided according to the section of the machine that was operated. The machine operator operates the front section together with the operator's desktop, whereas the operator's assistant - the side section with the ink set. Such a division of tasks was aimed at shortening the paths that the employees need to cover. That allowed for eliminating excessive walking and reducing time waste. The time saved in such a manner helped to balance the time spent on performing internal activities by the operator with external and internal operations performed by the assistant, particularly with regard to low-cost orders.

While performing tasks within the SMED method, the authors observed shortages in relevant production sections that would be responsible for preparing specific raw materials, components or fittings before executing another order. A particularly detrimental factor is a lack of a professional ink mixer, where an adequate ink is prepared beforehand and later it is fed into the ink tray. At present each ink is prepared by the printer, which additionally increases the waiting time. It would be advisable for the company to consider investing into e.g. an automatic dosing system. Eliminating the human factor in the process of ink preparation will increase the quality of work and positively affect the production process by ensuring the precision of ink dosing and mixing.

The company should also consider automating the preparation of printing rolls with polymers. Currently, similarly to the implementation of the SMED method - the process of preparing and assembling polymer sheets on printing rolls is conducted by one printer. In many modern printing companies this process is managed by separate sections that prepare sets of ready printing rolls for executing the each production order.

\section{EFFECTIVENESS EVALUATION OF IMPLEMENTED ACTIVITIES}

The application of a few relatively simple and low-cost solutions brought measurable benefits.

In order to evaluate the introduced improvements, the following indicators defining the effectiveness of the SMED method were applied:

- ERW indicator - reflects the effectiveness of reducing waste that results from the execution of redundant activities (1),

- ETA indicator - reflects the effectiveness of transforming activities (2),

- EOI indicator - reflects the effectiveness of organisational improvements (3),

- OESMED indicator - reflects the overall effectiveness of implementing the SMED method (4).

In order to define the value of the above indicators, the following templates were used [13]:

$$
E R W=\frac{\mathrm{TI}+\mathrm{TE}+\mathrm{TOI}}{\mathrm{TI}+\mathrm{TE}+\mathrm{TOI}+\mathrm{TR}}
$$

$$
\begin{gathered}
E T A=\frac{\mathrm{TI}+\mathrm{TOI}}{\mathrm{TI}+\mathrm{TE}+\mathrm{TOI}} \\
E O I=\frac{\mathrm{TI}}{\mathrm{TI}+\mathrm{TOI}} \\
O E S M E D=\frac{\mathrm{TI}}{\mathrm{TI}+\mathrm{TE}+\mathrm{TOI}+\mathrm{TR}}=\mathrm{ERW} * \mathrm{ETA} * \mathrm{EOI}
\end{gathered}
$$

where:

- TI - time of internal activities,

- TE - time of external activities, 
- TOI-time savings associated with the implementation of organisational improvements,

- $\quad \mathrm{TR}$ - time of redundant activities.

The value of the OESMED indicator shows by what percentage the changeover time has shortened. The previously defined indicators help to evaluate the effectiveness of the SMED method as a tool for shortening changeover time of technological machines and the efficiency of specific stages of this method. High values of the identified ETA and EOI indicators describe the areas, where there is a need for seeking additional solutions that improve the changeover process.

Table 5 presents the values of indicators for the machine Gidue Master Combat 430.

TABLE V. INDICATOR VALUES

\begin{tabular}{|l|c|}
\hline \multicolumn{2}{|c|}{ Efficiency indicators for the SMED method } \\
\hline ERW & Value \\
\hline ETA & 0.81 \\
\hline EOI & 0.60 \\
\hline OESMED & 0.71 \\
\hline Growth in efficiency [\%] & 0.35 \\
\hline
\end{tabular}

The value of the OESMED indicator constitutes 0.35, which means that changeover time is shorter by $35 \%$. The value of the EOI indicator constitutes 0.71 , which means savings in changeover time that result from organisational improvements at the level of $71 \%$. Thanks to the application of the SMED method, the efficiency of production increased by $20 \%$.

\section{CONCLUSIONS}

The application of the SMED method with regard to the flexographic machine eliminated unnecessary activities and improved the flexibility of production. Thanks to a detailed analysis of the presented results it became possible to propose improvement measures. However, it is significant to make suitable preparations before this method is introduced. This requires gathering precise data, conducting meticulous analyses and defining apt improvement activities. It should also be remembered that the final result considerably depends on the cooperation and engagement of all employees, starting with the operator up to the mediumand top-range management.

\section{REFERENCES}

[1] F. Birmingham and J. Jelilnek, "Quick Changeover Simplified The Manager's to Improving Profits with SMED”, New York: Productivity Press, 2007.

[2] A. Kujawińska, M. Rogalewicz, M. Diering and A. Hamrol, Statistical Approach to Making Decisions in Manufacturing Process of Floorboard, Advances in Intelligent Systems and Computing, Recent Advances in Information Systems and Technologies, Springer, March 2017, pp.499-508, DOI: 10.1007/978-3-319-56541-5_51.

[3] K. Szwedzka, J. Gruszka and P. Szafer, Impact of technical and technological changes on energy efficiency of production company case study, in: Cohal, V; Lobont, L; Topala, P; et al. (eds.), IOP Conf. Series: Materials Science and Engineering 145, 2016, 062007 DOI:10.1088/1757-899X/145/6/062007.

[4] M. Jasiulewicz-Kaczmarek and P. Drożyner, Preventive and ProActive Ergonomics Influence on Maintenance Excellence Level, in: M.M. Robertson (eds.), Ergonomics and Health Aspects, HCII 2011, LNCS 6779, pp. 49-58 @ Springer-Verlag Berlin Heidelberg ISBN 978-3-642-21715-9.

[5] G. Chauhan and T.P. Singh, Measuring parameters of lean manufacturing realization. Measuring Business Excellence. 16 (3), 2012, pp. 57-71.

[6] J. Pettersen, Defining lean production: some conceptual and practical issues, The TQM Journal Vol. 21(2), 2009, pp. 127-142.

[7] M. Rosen and H. Kishawy, Sustainable Manufacturing and Design: Concepts, Practices and Needs. Sustainability 4, 2012, pp. 154-174.

[8] L.L.L. Negrão, M. G. Filho and G. Marodin, Lean practices and their effect on performance: a literature review, Production Planning \& Control,28:1, 2017, pp. 33-56, DOI: $10.1080 / 09537287.2016 .1231853$.

[9] M. Jasiulewicz-Kaczmarek, Integrating Lean and Green Paradigms in Maintenance Management, in: E. Boje, X. Xia, (eds.) Proceedings of the 19th IFAC World Congress Cape Town, South Africa. August 2429, 2014, IFAC-Papers OnLine Vol. 47 Issue: 3, pp. 4471-4476, DOI 10.3182/20140824-6-ZA-1003.02213.

[10] T. Ohno, Toyota Production System: Beyond Large Scale Production, Productivity Press, 1988.

[11] S. Shingo, A revolution in manufacturing: the SMED system, Portland - Oregon: Productivity Press, 1985.

[12] M. Cakmacki, Process improvement: performance analysis of the setup time reduction-SMED in the automobile industry, International Journal of Advanced Manufacturing Technology 41, 2009, pp. 168179.

[13] K. Antosz and A. Pacana, Ocena efektywności wdrożenia metody SMED dla wybranych stanowisk produkcyjnych - studium przypadku, in Innowacje w zarządzaniu i inżynierii produkcji, vol. 1, R.Knosala (eds.), Opole: PTZP, 2017, pp. 313-321.

[14] S.Palanisamy and S. Siddiqui, Changeover Time Reduction and Productivity Improvement by Integrating Conventional SMED Method with Implementation of MES for Better Production Planning and Control, International Journal of Innovative Research in Science, Engineering and Technology, 2(12), 2013, pp. 1961-1974.

[15] H. D. Sherali, D. V. Goubergen and H. V. Landeghem,A quantitative approach for scheduling activities to reduce set-up in multiple machine lines. European Journal of Operational Research 187, 2008, pp. $1224-1237$.

[16] J.Oleśków - Szłapka, G.Pawłowski, Scheduling and lot sizing problems for variable range of products using GA-based method, Proceedings IFAC, Volume 49, Issue 12, 2016, pp. 662-667.

[17] D. Trietsch, Some notes on the application of Single Minute Exchange of Die (SMED), Monterey, California: Naval Postgraduate School, 1992, p. 10.

[18] M. Jasiulewicz-Kaczmarek, K. Szwedzka,Were our leaders ready to implement the changes? - a case study, in: X. G. Yue, N. J. R. Duarte (eds.), Proceedings of the 2016 International Conference on Economics and Management Innovations, part of Advances in Computer Science Research vol. 57, 2016,pp. 267-271 DOI: 10.2991/icemi-16.2016.6. 